UDC $343.13 ; 342.7(477)$

Klymchuk Valerii,

Leading Researcher of the State

Research Institute

MIA Ukraine, Kyiv, Ukraine

ORCID ID 0000-0001-7274-9617

\title{
PROBLEMS OF APPLYING THE CASE LAW OF THE EUROPEAN COURT OF HUMAN RIGHTS IN THE PRACTICE OF INVESTIGATIVE UNITS OF THE NATIONAL POLICE OF UKRAINE
}

The article is devoted to the theoretical and practical problems of applying the case law of the European Court of Human Rights in the criminal investigation of Ukrainian investigation units National Police of Ukraine, determining the place and role of decisions of the European Court in the national legal system as a source of criminal procedural law.

Study and analysis of the provisions of the Constitution of Ukraine, the new Criminal Procedural Code of Ukraine and the current legislation on the activities of pre-trial investigation units in Ukraine and the practice of their application during pretrial investigation of norms of international legal standards regarding the protection of the rights, freedoms and legitimate interests of a person, the case law of the European Court of Justice Human rights on these issues under the new criminal procedure law of Ukraine testify, that the essential shortcoming of the system of legislative provision of regulation of this activity of pre-trial investigation bodies is that the provisions of the new CPC led to a radical change in the domestic criminal-law doctrine. The revision and improvement of the current legislation, and in particular the important and determinative positions, such as the changes to the CPC and the Criminal Code, should be based on a thoroughly elaborated scientific concept based on real needs of existing practice and the development of public relations in the state.

It is precisely in the work of the bodies of the pre-trial investigation of the National Police that the situation of the fight against crime and the real state of 
protection of the rights, freedoms and legitimate interests of individuals and legal persons from criminal and other illegal encroachments are most clearly reflected. Therefore, the cardinal change in the criminal process in Ukraine in this part could not be introduced without fundamental research, taking into account the achievements of the leading domestic scientists in this field, as well as the introduction of the relevant law conditions. The legalization of these requirements by the legislator in the course of the work of the CPC in 2012 has led to a number of legislative mistakes, including in matters of ensuring the rights, freedoms and legitimate interests of a person in criminal proceedings. Despite the positive features of these and other innovations, the practice of applying during the pre-trial investigation of the norms of international legal standards regarding the rights, freedoms and legitimate interests of a person, the practice of the European Court of Human Rights on these issues under the new criminal procedure legislation of Ukraine testifies, that domestic criminal procedural legislation needs to be improved on the implementation of criminal proceedings in this area through the implementation of international legal standards. In connection with this, there is an urgent need to develop appropriate mechanisms for implementation, harmonization of normative legal acts, provisions of the new CPC of Ukraine with international legal acts on this issue, which are sources of criminal procedural legislation of Ukraine.

In this connection, it also appeared necessary to consider the problematic issues of the application of these standards and the need to revise and improve certain norms and provisions of the CPC of Ukraine, which regulate the grounds and procedure for this activity, as well as the development of a mechanism for the application of pre-trial investigations of the norms of international legal standards concerning ensuring the rights, freedoms and legitimate interests of a person, the case law of the European Court of Human Rights on these issues under the new criminal procedure law Ukraine.

Keywords: precedent, practice, implementation, decision, convention, application

\section{REFERENCES}


1. Kryminalnyi protsesualnyi kodeks Ukrainy. "Criminal Procedural Code of Ukraine": Law of Ukraine of April 13. 2012 № 4651-VI. Information from the Verkhovna Rada of Ukraine. 2013. No. 9-10, No. 11-12, No. 13. Art. 88. [in Ukrainian].

2. Pro vykonannia rishen ta zastosuvannia praktyky Yevropeiskoho sudu z prav liudyny. "On the implementation of the decisions and application of the practice of the European Court of Human Rights": Law of Ukraine dated February 23, 2006 No. 3477IV. Information from the Verkhovna Rada of Ukraine (IVRU), 2006, No. 30, 260 p. [in Ukrainian].

3. Konventsiia pro zakhyst prav liudyny i osnovopolozhnykh svobod vid 4 lystopada 1950 r. "Convention for the Protection of Human Rights and Fundamental Freedoms of November 4, 1950". URL: http://zakon.rada.gov.ua/laws/show/995_004 (date of application: 02.09.19) [in Ukrainian].

4. Nedbailo P.E. (1960) Primeneniye sovetskikh pravovykh norm."Application of Soviet legal norms". M. 335p. [in Russian].

5. Hroshevyi Yu.M. (2018) Kryminalnyi protses Ukrainy. "The criminal process of Ukraine". / For ed.U.M.Hroshevoho and V.M. Khotenets. Kharkiv Right. 496 p. [in Ukrainian].

6. Blazhivska N.Ye. (2018) Do pytannia pro mistse rishen Yevropeyskoho Sudu $\mathrm{z}$ prav liudyny u natsionalnii pravovii systemi. "On the Place of Decision of the European Court of Human Rights in the National Legal System": Entrepreneurship, Economy and Law. International Law, No. 4/2018. 228p. [in Ukrainian].

7. Butkevych O.V. Chy ye rishennia Yevropeiskoho sudu $\mathrm{z}$ prav liudyny oboviazkovymy dlia Ukrainy, yak tsoho vymahaie zakon?. "Are the decisions of the European Court of Human Rights binding on Ukraine as required by law?" 279 p.

http://dspace.onua.edu.ua/bitstream/handle/11300/9583/Butkevich\%20279293.pdf?sequence $=1 \&$ is Allowed=y (date of application: 20.08.2019) [in Ukrainian].

8. Konstytutsiia Ukrainy. "The Constitution of Ukraine": Law of 25.06.1996 No. 254k / 96-VR. Information from the Verkhovna Rada of Ukraine. 1996. No. 30. Art. 141. [in Ukrainian]. 
9. Koruts U.Z. (2015) Mizhnarodno-pravovyi zakhyst prava na spravedlyvyi sudovyi rozhliad v praktytsi Yevropeyskoho Sudu z prav liudyny ta pravozastosovna praktyka Ukrainy. "International legal protection of the right to a fair trial in the practice of the European Court of Human Rights and the law practice of Ukraine": diss. Ph.D., Kyiv. 3p. [in Ukrainian].

10. Terletskyi D.S. Mizhnarodni dohovory yak skladova natsionalnoho zakonodavstva Ukrainy "International treaties as a component of the national legislation of Ukraine": Legal Ukraine. Lawyer. Library of scientific legal periodicals. URL:

http://www.pravnuk.info/urukrain/978-mizhnarodni-dogovori-yak-skladovanacionalnogo-zakonodavstva-ukra\%D1\%97ni.html (date of application: 04.08.19) [in Ukrainian].

11. Popov Yu.Yu. (2010) Rishennia Yevropeiskoho sudu z prav liudyny yak perekonlyvyi pretsedent: dosvid Anhlii ta Ukrainy. "Decision of the European Court of Human Rights as a compelling precedent: the experience of England and Ukraine". Center for Commercial Law. Entrepreneurship, economy and law. No.11.51p. URL: http://popov-yuyu.narod.ru/28_ECHR_case-law.htm. (date of application: 04.09.19) [in Ukrainian].

12. Plan zakhodiv shchodo realizatsii Natsionalnoi stratehii u sferi prav IIudyny do 2020 r. "Action Plan for Implementation of the National Strategy for Human Rights by 2020": Resolution of the Cabinet of Ministers of Ukraine dated November 23, 2015 No. 1393-p. \{As amended by the CMU Decree No. 322 of 1.05.2017. Government courier dated 30.12.2015. No. 245. [in Ukrainian].

13. Uvarov V.H. (2014) Mizhnarodno-pravovi standarty u kryminalnomu protsesi Ukrainy. "International legal standards in the criminal process of Ukraine": monograph / V.H. Uvarov. Kharkiv: NikaNova. 95 p. [in Ukrainian]. 